\title{
The Effect of Limb Length on Speed of Mawashi Geri Kick in Karate Kumite for Adult
}

\author{
N Ihsan \\ Sport Science Faculty, Universitas Negeri Padang, jln. Prof Hamka, Indonesia \\ *Corresponding author. Email: nurul_ikhsan@ymail.com

\begin{abstract}
ABTRACT
The purpose of this study is to determine whether there is a significant difference in limb length with the speed of mawashigeriin karatekumite. This is a comparative study with twenty purposively selected 17 years old female karate participants. The instrument used to measure the limb length was anthropometer and to measure the speed of mawashigeri kick was Nurul shark test. T-test was used to analyze the data. The result shows that there was no significant difference in limb length to the speed of mawashigeri kick of karate kumite at Dojo Home Bushido Kota Padang.
\end{abstract}

Keywords: Limb length, mawashi geri kick, karate kumite

\section{INTRODUCTION}

Many kinds of sport that can be selected by the community to be a medium of communication. One of them is karate. Karate is one of the most developed martial arts in Indonesia. Like other martial arts, although it is known and seem to have a lot of violence, but karate still remains to be one of the favorite sports in the world including in Indonesia.Children, adolescents, adults, parents, both man and woman like karate. Even for some people who are very fond and have joined karate in most of their life use this martial arts as the motto and the way of life. Bermanhot Simbolon explains that "Theare three techniques contained in karate, they are Kihon (basic technique), Kata (jurus), and Kumite (fight)" According to Supriyadi among the three main techniques the number of matches in karate is usingkata and kumite (2012: 34).

In order to get an achievement optimally a karate athlete is required to master kihon (basic technique) in karate. Good mastery of kihon is one of the important factors controlled by every karate athlete in order to master both kata and kumite techniques. There are many kinds of kihon movements in karate, such ashit, parry, kicks, and horses. In this time, the writer researches more about kihon movement in kicks, especially mawashi gerikick(circular kick). According to Sujoto J. B (1996: 103) in Simatupang (2015); Mawashi geri is a straight kick that is done turning the hip from beside towards the head.

In doingmawashi geri kick, the athlete is required to have the physical components one of which is the speed in order to kick properly and efficiently sowhen doing opponent's kick does not catch the kick leg so that the risk of injury can be avoided. Mawashi geri kick is often used in karate match, generally in fighting class or called kumite, because the points earned from this kick technique is 3 (ippon) for jodan and 2 (waza-Ari) for chudan direction.

Biomechanically mawashi geri begins from the raised knee and being swung from the outside to insidealong with twisting the body. The sole of foot pivot is also twisted at the end of the palm. The kick legis to hit the target usingthe instep. After done kicking, place your feet in the desired position, in front or behind.

According to Dougall, (1992) (Pradana, 2013) in Muryanto (2017: 5). The length of the limbs is from the bottom of the heel to the waist. While the speed of kick is the velocity of the segments or body parts in the form of a combination of upper limbs and lower limbs. The length of thelimbswhich is a part of the body posture determines the achievement. As stated by Simatupang (2015) that one of the biological aspects that participate in determining the achievement in sports that is the body's structure and posture. The limbs determine a karate-ka in doing a kick. The more trained one's limbs the more qualified karate-ka technique kicks are done.

Long limbs require more time to get to the target (head) when doingmawashi geri than short limbs, because short limbs have fewer distances. Therefore karate-ka that has shortlimbs has more speed. But Syafruddin (3013: 47) suggests antophometri traits of the human body such as the ratio of the length of limbs 
to body, and the length of arm play an important role in increasing speed. Based on these problems the authors consider that it is important to know how much the difference a karate-ka that has long limbs from karate$\mathrm{ka}$ who has short limbs to the speed of mawashi gerikick, karate-ka's kumite, especially at Dojo Home Bushido Padang.

Kumiteis an exercise method that aims to train karate techniques both attack and defense techniques that is done in pairs. The scoreconsists of sanbon score (three points), waza-ari (two points) and yuko (one point). One score of Sanbon is same with three ippon scores. A technique will get sanbon score if it meets the criteria of assessment such as: good form, right attitude, exciting performance, zanshin, right time and right distance. According to Simatupang (2015) in the kumite game, the techniques that play the important roles to gain scores are hit technique, jolt technique, and kick technique.

Mawashi geri kick is a very important technique that should be mastered by a karate-ka because this kick technique can be used to attack the opponent or to cut off the opponent's attack. In addition mawashi geriis also often used to pursue the acquisition of points and even reverse the situation when an athlete's acquisition points left behind. The most important thing to be aware in doing mawashi gery kick is kicking with the consideration of the distance and the jolt should get the target, so in this technique is desperately needed the speed of the limbs.

The length oflimbs is from the bottom of the heel to the waist (Dougall, 1992, in Pradana, 2013). The length of the limbs is divided into two, which are the upper and lower limbs. The upper limb is from spina illiaca and the upper part and middle limits of condylus tibialis. The lower limb is from the tibialcenter and malleoulus center or footwear (Anatomy team, 2003, in Rafsanjani, 2012). The length of the limbs as a part of the posture is very important for the kick ability especially mawashi geri, and as one of the lower motion, limbshave an important role in sports performance. As a part of the body lower motion, the length of the limbsfunctions as a base to the upper body parts, as well as the determinants of movement in moving, stepping, jumping, and processing mawashi geri kicks.The limbs are classified into the lower body part, divided into three parts: 1) Upper limb, upper limb is thigh, from groin to knee, in anatomical terms is called femur. The femur bone is a long bone like a tube, 2) The lower limb is the lowerpart or calf part that is from the ankle knee, which in anatomical terms is called leg. This lower limb consists of two bones, tibia or shin bone which is the main skeleton of the lower limbs, like a tube, and the other one is fibular bone or calf bone (Masrip, 2007: 23) and 3) The Soleis composed of tarsal, meta tarsal, and falaxbones. Tarsal bones or leg bones consist of seven collective bones called tersus. This bone supports the weight when standing up.

Speed is the ability to complete a certain distance quickly (Bompa \& Haff, 2009: 315, in Syafruddin 2013: 88). Speed in Nurul(2014) is a person's ability to do continuous movement in the same form in the shortest time. Meanwhile, according to Soeharno HP in Prihastono Arief (1994: 67), he states that speed is a quality condition of the athlete that gives the possibility to react as quickly as possible to an excitatory, and then able to perform in the form of motion as quickly as possible.

Based on some definitions of the speed conveyed by the experts above, it can be concluded that the speed is a component physical conditions required to perform movements respectivelyor move the body from certain positions to another position at a certain distance in the shortest time.Kick speed is the speed motion of the segments or body parts in the form of a combination of upper limbs and lower limbs. The kick includes in the category of acyclic movements influenced by static power and the speed of contraction. The definition of speed itself is the distance traveled by time unit, so to produce a fast kick, the fighter must complete the distance to the target in the shortest time (Mahardhika, 2013, in Muryanto, 2017)

Basically, speed is distinguished by reaction speed and action speed (movement). The reactionspeed consists of a simple reaction speed (easy) and a complex reaction speed (difficult), while the action speed can be distinguished by cyclic action speed and acyclic action speed (nurul; 2017). Thereaction speed is the ability to respond to acoustic, optical, and tactile stimuli quickly (Syafruddin 2013: 88). Acoustic stimuli is stimulus or signal received through the sense of hearing such as the gun shotwhen starting a shortdistance run, and can also be a whistle, clapping hands and so on. While optical stimuli is a stimulusthat is received through the sense of sight (eyes), for example, a person acts or moves by noticing the movements of his coach's hand and following the direction of the movement by moving forward, backward, to the right and left side. It can also be from stimulation of light, colors, balls and others. While tactile stimuli is stimulus received through the sense of touch (tactile), for example a touch to the skin. Because of the differentreaction speed required in every sport, the experts distinguish the reaction speed to a simple reaction speed and complex reaction speed. The action speed (movement) is defined as the ability with the help of central nervous system and muscle movement can perform movements in minimal time units (Syafruddin 2013: 93). This action speed can occur in the form of the speed of body movement and the speed of moving parts of the body like the movement of hands and feet that take place separately. When viewed from the movement phase stages and movement speed 
characteristics contained in the sport, the movement speed (action) can be distinguished by cyclic action speed and the acyclic action speed.

\section{METHOD}

This study is an exposfacto research with comparative approach. The sample in this research is all female karate-ka kumite at Dojo Home Bushido Padangtotal14 persons. The instrument used to test the limb length isanthropometer; the lengthis measured by reducing the result of height with height of sitting, andto testmawashi gerikick speed uses Nurul shark test. To test the hypothesis proposed in this study, the data obtained is the differenceofkarate-ka kick speed that have long limbs and short limbs, analyzed with the previous $\mathrm{t}$ test has been done analysis of analysis requirements that is test data normality with liliefors test and test datahomogeneity.

\section{RESULTS}

The results obtained by the researcher are as follows:

\section{The Karate-Ka Kick Speed with Long Limbs}

The result of the calculation of karate-ka kick speed that have long limbs from sevensamples( $\mathrm{n}=7)$, obtained the maximum score is 0.46 for the highest scoreand 0.63 for the lowest score, the average (mean) is 0,56 and standard deviation is 0,006 .

\section{Kumite Karate-ka KickSpeedwith Short Limbs}

The result of the calculation of karate-ka kick speed with short limb from sevensamples $(n=7)$, obtained the maximum score is 0,52 for the highest score and 0,60 for the lowest score, the average (mean) is 0,56 and standard deviation is 0,60 .

The result of t-test analysis shows that there is no significant difference of karate-ka that have long limbs and short limbs to the kickspeed ofmawashi geri karate, it is shown from the acquisition of $t_{\text {hitung }} 0,00>$ $\mathrm{t}_{\text {table }} 2,179$.

The result of the analysis shows that there is no significant difference between the length of the limbs to the kick speed of mawashi geri karate-ka at Dojo Home Bushido Padang. It is proved by the $t$ test value as $t_{\text {hitung, }}$, kick speed of karate-kawhose long limbsand short limbs is 0,00 and $t_{\text {table }}$ at $5 \%$ significant level is 2,179 . Because thitung $>$ ttabel

\section{CONCLUSION}

Based on the results of the research that has been discussed, it is concluded that: First, there is no difference between karate-ka who have long limbs and thosewho have short limbs to the speed of mawashi gerikick.
Based on the above conclusion, the researcher can provide suggestions as follows:

1. For the trainer: to be able to provide the trainings that can increase the ability of muscle explosive power and mastery of techniques moreso that the speed of karate-ka kicks can be increased by not considering the size of the limbs.

2. For athletes or karate-ka is to keep practicing well so that the training process can give the maximum impact on increasing the speed of kicks.

\section{REFERENCES}

[1] Suharsimi Arikunto. (2002). Prosedur penelitian. Jakarta : Rineka Cipta

[2] Suharsimi Arikunto. (2013). Ilmu Kepelatihan Olahraga : Teori dan Aplikasinya dalam Pembinaan Olahraga. Padang : UNP Press

[3] Arikunto (1990). Metode Penelitian Jakarta : Angkasa

[4] Hamid, Apris, (2007). Teknik Dasar Karate (kihon). Padang

[5] Harsono. (1988). Panduan Kepelatihan. Jakarta: KONI

[6] Ihsan, N. Development of Speed Measurement System for Pencak Silat Kick Based on Sensor Technology

[7] IOP Conference Series: Materials Science and Engineering 180 (1), 012171 | vol: | issue : | 2017

[8] Nurul Ihsan, 2018. Instrumen Kecepatan Tendangan Pencak Silat Berbasis Teknologi. Jurnal Sosioteknologi 17 (1), 124-131

[9] Nurul Ihsan. 2018. Sumbangan Konsentrasi terhadap Kecepatan Tendangan Pencak Silat. Media Ilmu Keolahragaan Indonesia. Volume 8. Nomor 1. Edisi Juni 2018.

[10] Nurul Ihsan. The analysis of the physical condition, will pencak silat construction training center students (PPLP) of West Sumatra. International Seminar of Sport Culture and Achievement, 307 | vol: | issue : | 2014

[11] Simatupang, Janter Ignatius,(2015), Kontribusi Power Otot Tungkai, Pamjang Tungkai dan Keseimbangan Terhadap Kecepatan Tendangan Mawashi Gery di Ranting Karate Bushido Bandar Lampung, Bandar Lampung : Fakultas Ilmu Pendidikan Universitas Lampung Bandar Lampung

[12] Simbolon, Bermanhot, Sp. d, (2004), Latihan dan Melatih Karateka : Dasar, Teknik, Taktik, Strategi,Ilmu, Norma, Program, Latihan Psikologi Olahraga dan Analisis Karate .Yogyakarta : Griya Pustaka

[13] Suwirman. (2011). Metodologi Penelitian. Padang

[14] Syafrudin. (1999). Panduan Teknis Tes, dan latihan Kesegaran Jasmani.Hotel Sahid Jaya :Jakarta 
[15] Syahputra, Yolanda,(2015), Judul Skripsi : Kontribusi Panjang Tungkai dan Flesibelitas Sendi Panggul Terhadap Hasil Tendangan Ushiro Geri dalam Karate, Bandung :Program Studi Pendidikan Kepelatihan Olahraga Fakultas Pendidikan Olahraga Kesehatan Universitas Pendidikan Indonesia

[16] Wahid, Abdul, (2007), Shotokan Sebuah Tinjauan Alternatif Terhadap Aliran Karate-do Terbesar di Dunia. Jakarta: PT. Raja Grafindo Persada

[17] Zalfendi, dkk. (2011), Gizi Olahraga. Padang : Sukabina Press 